\title{
THE RELATIONSHIP BETWEEN RELATIONSHIP-ORIENTED LEADERSHIP, ORGANIZATIONAL EMOTIONAL MEMORY LEVEL AND ORGANIZATIONAL COMMITMENT
}

*Arzu GIRISKEN (Orcid ID: 0000-0003-0295-7976)

*Altınbaş University, Turkey

\begin{abstract}
Leadership in the business environment helps to establish and maintain effective relationships between employees by reducing the level of stress at work and increasing job satisfaction. Hence, it reduces absenteeism and employee turnover as well as improves performance. The relevant literature includes studies that examine the relationship between leadership, organizational memory level, and organizational commitment. However, there is no study discussing the relationship between relationship-oriented leadership, organizational emotional memory level and organizational commitment. This research paper is the extended version of a conference paper (in 2018) that it empirically tests the effect of relationshiporiented leadership on organizational emotional memory level and organizational commitment. The research was carried out with a sample consisting of 320 participants from organizations in the service sector in Istanbul in 2018 by using a survey method. The result of the research showed that 1) relationshiporiented leadership has no relationship with the level of organizational emotional memory level, 2) relationship-oriented leadership has negative relationship with organizational commitment, 3) organizational emotional memory level has a positive relationship with organizational commitment. Mainly, employees were reactive to a relationship-oriented leadership style both in terms of organizational commitment and organizational emotional memory level. This research has been applied to the employees of Turkey's three major durable goods companies. As a result of this study, the relationship found between relationship-oriented leadership and organizational commitment shows a negative relationship unlike the literature. The main reason for the difference is that relationship-oriented leadership does not fit well with the working styles of those working in the durable goods industry. Instead of developing communication with employees that ends up more time pressure on them, output-oriented leadership type is seemed to be more suitable for this sector. When approached with the relationship-oriented leadership type, it was observed that the employees were less attentive to their work (because they were not warned seriously enough) and as a result, their commitment to the organization decreased. If the sector researched in this study had been different, it has been predicted that a more positive relationship between organization commitment and relationship-oriented leadership could be obtained.
\end{abstract}

Keywords: Relationship-Oriented Leadership, Organizational Emotional Memory Level, Organizational Memory, Organizational Commitment

\section{INTRODUCTION}

Today, leadership has become a key concept in organizational structures. Organizations understood the importance of leading skilled managers to ensure that their teams take part in organizational structures in the most effective way. At this point, it is important to know how leadership is related to other important factors for organizations such as organizational commitment and organizational emotional memory level. Loyalty to their institutions is a very important concept for employees and relationship-oriented leadership can affect the level of loyalty. Increasing loyalty is expected to decrease employee turnover and enhance organizational performance.

There are studies for relationship-oriented leadership (Rüzgar, 2018; Patterson, 2018; Sahertian, 2018; Zehir et. al., 2011), organizational emotional memory level (Al Fouri et. al, 2014; Lorestani \& Faiz, 2017) and organizational commitment (Aube \& Morin, 2007; Benkhoff, 1997; Finegan, 2000; Rageb \& Farid, 2014) seperately, however there are no studies observing the impact of relationship-oriented leadership on 
organizational memory level and organizational commitment in the literature. In this study, the mediatory effect of relationship-oriented leadership on the relationship between organizational commitment and organizational emotional memory level is also examined.

In the highly competitive business environment it will be beneficial for business professionals and management academics to understand the new concepts in management. Relationship-oriented leadership is the first concept that will be focused.

\section{RELATIONSHIP-ORIENTED LEADERSHIP}

Relationship-oriented leadership is associated with establishing relationships with people, promoting cooperation and teamwork, increasing job satisfaction of employees, and developing behaviors to ensure integration with the organization. In addition, (1) supporting, (2) developing, and (3) recognizing behavior patterns form the basis of relationship-oriented leadership (Yuk1, 2002: 61).

Relationship-oriented leadership style is mainly focusing on developing personal relationships, showing approval and enhancing inspiration. These leaders support their employers by listening and giving advices to them. (Tran, Q. H., 2020)

Supportive leadership behavior includes considering and accepting the feelings and needs of other people. It helps to establish and maintain effective interpersonal relationships. Some forms of supportive behavior reduce stress levels at work as well as increase job satisfaction. Increasing job satisfaction and decreasing stress lower absenteeism and employee turnover in the workplace, thus increasing performance (Yukl, 2002: 63). Studies have shown that supportive leaders have high levels of satisfaction with their employees, managers and their jobs; however, it does not support the argument that supportive leadership improves the performance of employees (Yukl, 2002: 64). As the employees, especially supervisors are more likely to exhibit relationship-oriented leadership to fulfill team needs. (Briker, Walter \& Cole, 2020).

Few studies have discussed mediating factors such as elevation of employees' self-confidence, reduction of stress, trust in their superior and willingness to do more for their superior that affects the relationship between supportive leadership behavior and performance (Vroom \& Jago, 1988: 32; Bragg \& Andrews, 1973: 728; Cooper \& Wood, 1974: 128; Yukl, 2002: 65).

Developing leadership behavior, on the other hand, includes managerial activities that help individuals develop their abilities and allow for job arrangement and career development. Coaching, mentoring, and career counseling are among developing leadership behaviors. This type of leadership behavior provides leaders, employees, and organizations with many benefits. The benefits for employees include better job organization, faster career development, an increase in self-confidence, and development of professional ability. The potential benefit for leaders is that they feel satisfied as they are helping others gain experience and develop. Benefits such as an increase in organizational performance, commitment of employees to the organization, and the number of potential people who can be promoted to positions that require high-level responsibilities can be regarded among the contributions of developing leadership behavior to the organization (Yukl, 2002: 66; Goldstein, 1986: 21; Bradford \& Cohen, 1984: 12).

Recognizing leadership behavior includes praising and appreciating others for their effective professional performance, recognizing significant progress, and a substantial contribution an employee has made to the organization. This type of leadership can be in the form of praise, reward, or award ceremony. The relevant literature emphasizes a positive relationship between rewards and employee satisfaction; however, it has been reported that there is no consistent relationship with performance (Kim \& Yukl, 1995: 362; Lowe et al., 1996: 386; Podsakoff \& Todor, 1985: 56; Yukl, 2002: 67). Although descriptive studies have noted that effective leaders should appreciate, recognize, and praise their employees on their development, some empirical studies have found a negative relationship between praise and performance (Kluger \& DeNisi, 1996: 255).

\section{ORGANIZATIONAL EMOTIONAL MEMORY LEVEL}

When the concept of memory is examined from an organizational aspect, we can see that it is related to the transfer of the organization's accumulation of knowledge to the future and that it consists of mass beliefs, behavioral patterns, and material memory units that have differences in terms of their content, dissemination, access, and level. Organizational memory fulfils the function of transmission of the organization's knowledge to the future, enhances input efficiency, improves efficiency of decision-making 
processes and helps to establish an understanding among stakeholders of the organization (Cote, 2014: 9). The mood aspect of organizational memory is also very important. In addition to the cognitive elements of organizational memory, the element of emotion is also regarded as a concept that needs to be examined individually. As a result of studies conducted by Akgün et al. (2012: 10), the new concept of 'organizational emotional memory' has entered into the literature.

With its most general definition, organizational emotional memory is defined as the storage of emotional experiences and events that occur unconsciously over time. Thanks to the organizational emotional memory, knowledge and skills in the brains of each individual in the organization are made available to the organization. General knowledge and skills are acquired and procedures are kept in usage documents through group work (Holan, 2011: 13). Technically, creation and implementation of organizational emotional memory enable the use of information which is carried from the past to the present in the most general sense in current activities. As a result, efficiency of the organization is increased. Development of organizational emotional memory systems also plays an important role in increasing the efficiency of the organization. Organizational performance can also be at the desired level in organizations that have adopted organizational emotional memory. Using these tools to increase the sharing of information to be used in the formation of organizational emotional memory will also boost commitment to the organization (Alvesson, 2013: 15).

The organizational emotional memory level refers to the extent to which emotional memory is accumulated in an organization and the level reached as a result of this accumulation. Antonakis et al. (2009) discussed the organizational emotional memory level as the sum of emotional memory accumulated in all stakeholders and non-human elements of the organization. Theoretically, the organizational emotional memory level is considered as the result of the existing emotional memory in organizational emotional memory storage units. From an operational point of view, emotional memory, which is inactive, that is, it cannot be used in the activities of the organization, is not included in the organizational emotional memory level. In other words, emotional memory stored in a stakeholder is idle unless it can be included in the activities of the organization and makes no operational sense.

\section{ORGANIZATIONAL COMMITMENT}

The concept of organizational commitment first began to attract the attention of academic researchers in the late 1960s and academic interest has continued to increase since the 1970s. Organizational commitment measures emotional relationships, how individual participate and their membership understandings, needs and desire to continue being as the part of the organization (Aram, Jameel. \& Abd Rahman, 2020).

Among the main reasons for continued interest in the concept of organizational commitment is the intrigue in identifying the ties of stakeholders to the organization they belong to and seeing it as an important place (Kim \& Brymer, 2011, p. 7). Today, commitment level of the stakeholders of the organizations to the specific organization is regarded as one of the most important issues in terms of the individual performance of the stakeholders. Employees' attitudes and behaviors toward the organization are directly related to their organizational commitment levels (Snape \& Redman, 2010, p. 9).

For organizations to survive in the conditions of fierce competition, stakeholders must be committed to the organization's goals and objectives. Employees' attitudes and behaviors toward the organization, as well as having the necessary equipment, directly affect individual and organizational performance. There is a direct proportional relationship between the positive attitudes and behaviors of the stakeholders and the strength and performance of the organization. Therefore, attitudes and behaviors of the stakeholders and their commitment to the goals and objectives of the organization are of vital importance for the organization (Ashfort et al., 2011, p. 3).

\section{RESEARCH METHODOLOGY}

The literature includes studies that examine the relationships between leadership, organizational memory and organizational commitment. However, there is no study investigating the relationship between relationship-oriented leadership with organizational emotional memory level and organizational commitment. This research empirically tests the relationship between relationship-oriented leadership, organizational emotional memory level and organizational commitment (no relationship) as well as the moderator role of relationship-oriented leadership in the effect (no relationship) of organizational emotional memory level on organizational commitment (positive relationship). 
The research was carried out with a sample consisting of 320 participants between 24-49 years old, from organizations in the service sector (3 leading durable goods companies) in Istanbul in 2018 by using an online quantitative survey method. $39 \%$ of the participants were women and $72 \%$ of the participants were white collard. The sample tolerance is $5.6 \%$ in $95 \%$ confidence interval.

Figure 1. Research Model

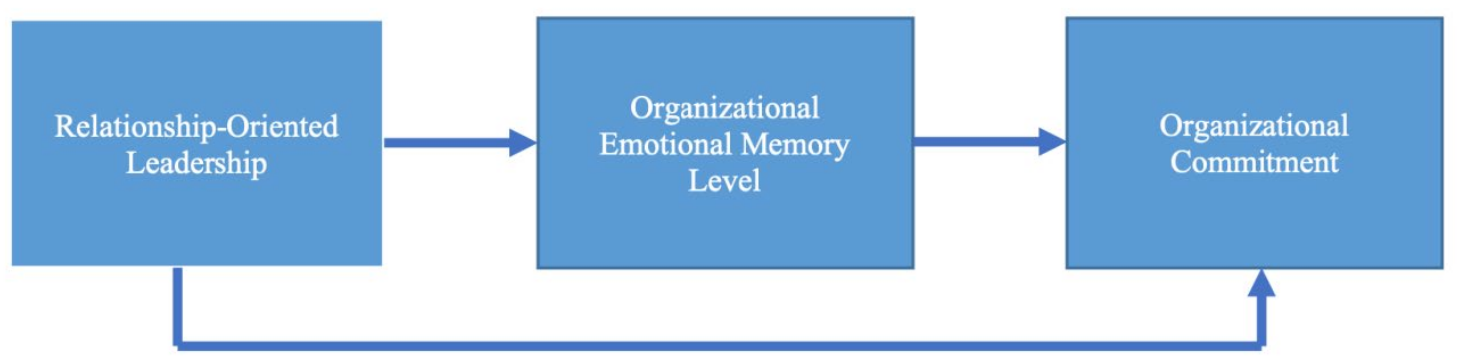

According to the research model, there are three hypothesis:

H1: There is a relationship between Relationship-Oriented Leadership and Organizational Emotional Memory Level.

H2: There is a relationship between Relationship-Oriented Leadership and Organizational Commitment.

H3: There is a relationship between Organizational Emotional Memory Level and Organizational Commitment.

\section{RESEARCH ANALYSIS \& FINDINGS}

Statistics is a science that concerns collection, classification, organization, and presentation of numerical data. It is a technique used to make the data collected through scientific methods meaningful. Descriptive statistics, on the other hand, includes methods and techniques used for collecting, describing, and presenting numerical data.

Before the variables in the theoretical model were subjected to factor analysis, the Kaiser-Meyer Olkin (KMO) measure of sampling adequacy was performed to determine whether the data obtained from the pre-application were suitable for factor analysis. In addition, the diagonal values of the anti-image correlation matrix were examined using Bartlett's sphericity test. The KMO result was calculated at 0.88 , which is considerably higher than the lower limit of 0.70 , which is considered statistically significant. Bartlett's sphericity test results also indicated a significant relationship.

Table 1. KMO and Bartlett's Test for Sphericity

Kaiser-Meyer Olkin (KMO) measure of sampling adequacy

0.883

Bartlett's Test for Sphericity

\begin{tabular}{ll} 
Chi-Square & 4.375 .080 \\
\hline $\mathrm{df}$ & 105 \\
\hline Sig. & 0.000
\end{tabular}

In the next stage, variables such as Relationship-Oriented Leadership (ROL - 5 measures), Organizational Emotional Memory Level (OEML - 14 measures), and Organizational Commitment Level (OCL - 7 measures) were subjected to factor analysis. As a result of the factor analysis, 11 questions in the effective relationship scale were excluded from the scale because they showed a factor distribution below 0.50 and fell to different factors by reducing the reliability. The remaining 15 questions were divided into 3 factors. The variables included in factor analysis together with their factor loadings are shown in the table below: 
Table 2. Factor Analysis Results

Rotated Variable Matrix

\begin{tabular}{|c|c|c|c|}
\hline & \multicolumn{3}{|c|}{ Variable } \\
\hline & 1 & 2 & 3 \\
\hline ROL4. Appreciates the contributions and achievements of employees & 0.870 & & \\
\hline ROL3. Consults employees when making decisions that affect them. & 0.863 & & \\
\hline ROL2. Informs employees about activities affecting them. & 0.840 & & \\
\hline $\begin{array}{l}\text { ROL1. Also establishes relationships with employees regarding issues outside } \\
\text { of work. }\end{array}$ & 0.828 & & \\
\hline ROL5. Helps employees to resolve disputes, conflicts, disagreements. & 0.820 & & \\
\hline $\begin{array}{l}\text { OEML5: Emotional experiences we have gained at our organization from the } \\
\text { past are reflected in the working environment through aesthetic design, } \\
\text { brochures, meeting rooms, corridors, sculptures and artwork. }\end{array}$ & & 0.770 & \\
\hline $\begin{array}{l}\text { OEML 7: The emotional experience we have gained from the past is used as a } \\
\text { guide to support the decision-making process at our organization. }\end{array}$ & & 0.763 & \\
\hline $\begin{array}{l}\text { OEML13: Emotional experience we have gained from the past is used for } \\
\text { solving customer problems at our organization. }\end{array}$ & & 0.739 & \\
\hline $\begin{array}{l}\text { OEML12: Emotional experience we have gained from the past is used to } \\
\text { compete with rivals at our organization. }\end{array}$ & & 0.708 & \\
\hline $\begin{array}{l}\text { OEML6: Emotional experiences we have gained from the past are used for } \\
\text { determining the strategies related to the activities we carry out at our } \\
\text { organization. }\end{array}$ & & 0.694 & \\
\hline $\begin{array}{l}\text { OEML1: Emotional experience we have gained from the past is used for } \\
\text { solving problems at our organization. }\end{array}$ & & 0.679 & \\
\hline OCL4: Teamwork is more important than individuality at our organization. & & & 0.807 \\
\hline OCL3: Employees of our organization are open and honest with each other. & & & 0.775 \\
\hline OCL6: My colleagues give me confidence in my work. & & & 0.750 \\
\hline OCL7: Our organization has a warm working environment. & & & 0.688 \\
\hline Extraction Method: Principal Component Analysis & & & \\
\hline Rotation Method: Varimax with Kaiser Normalization & & & \\
\hline
\end{tabular}

The literature review has shown that the reliability analysis is performed before the validity analysis especially in scale development studies. The reason behind this is the fact that a scale which is unreliable cannot be valid. Reliability analysis means that a measuring tool yields consistent similar results in all cases. If reliability is not provided for a scale, there is no need to conduct a validity study (Çelik \& Bindak, 2005). Statements prepared should be examined in terms of their consistency, determination, and the power to receive the reactions that are desired to be observed without evoking reactions. 
Table 3. Reliability Analysis Results

\begin{tabular}{llc} 
Variables & Number Count & Cronbach's Alpha $(\boldsymbol{\alpha})$ Values \\
\hline Relationship-Oriented Leadership & 5 & .900 \\
\hline Organizational Emotional Memory Level & 6 & .854 \\
Organizational Commitment & 4 & .793
\end{tabular}

After the factor analysis, reliability analysis was conducted to determine the internal consistency of the measurement by taking into account the average relationship between the variables. According to the literature, measurements with a Cronbach's alpha coefficient of 0.70 and above, as stated by Nunnally (1978), are considered sufficient (Nunnally, 1978; Hair et al., 2000).

It was determined that this resulted from the negative attitude of the employees toward their leaders or senior management due to the intense pace of work in the service sector. As a result of the attitudes and behaviors of the organization employees toward top management, their commitment to the institution lessens and they do not think of themselves as a part of the institution.

The predicted research hypotheses were tested using regression analysis. On examining the findings obtained as a result of the regression analysis,

Table 4. Regression Analysis Results

\begin{tabular}{cccccc}
\hline Independent Variables & Dependent Variables & $\begin{array}{c}\text { Standard } \\
\boldsymbol{\beta}\end{array}$ & Sig. & $\begin{array}{c}\text { Adjusted } \\
\mathbf{R 2}\end{array}$ & $\begin{array}{c}\mathbf{F} \\
\text { Value }\end{array}$ \\
\hline $\begin{array}{c}\text { Relationship-Oriented } \\
\text { Leadership }\end{array}$ & $\begin{array}{c}\text { Organizational } \\
\text { Emotional Memory } \\
\text { Level }\end{array}$ & -.119 & .003 & .013 & 8.642 \\
\hline $\begin{array}{c}\text { Relationship-Oriented } \\
\text { Leadership }\end{array}$ & $\begin{array}{c}\text { Organizational } \\
\text { Commitment }\end{array}$ & -.098 & .016 & .008 & 5.849 \\
\hline $\begin{array}{c}\text { Organizational Emotional } \\
\text { Memory Level }\end{array}$ & $\begin{array}{c}\text { Organizational } \\
\text { Commitment }\end{array}$ & .574 & .000 & .328 & 292.881 \\
\hline
\end{tabular}

As a result of the regression analysis of the relationships between the variables, the relationships between all the variables are statistically significant except one where there was no statistically significant correlation between the independent variable relationship-oriented leadership and the dependent variable organizational commitment. Regarding the effects of independent variables on dependent variables, as the standard $\beta$ value is significant at the level of $* *$ : $p<0.05$ and $* * *: p<0.001$ according to Sig value, two hypotheses were supported.

Table 5. Regression Analysis Results

\begin{tabular}{cccccc}
\hline $\begin{array}{c}\text { Independent } \\
\text { Variables }\end{array}$ & $\begin{array}{c}\text { Dependent } \\
\text { Variable }\end{array}$ & $\begin{array}{c}\text { Standard } \\
\boldsymbol{\beta}\end{array}$ & Sig. & $\begin{array}{c}\text { Adjusted } \\
\mathbf{R 2}\end{array}$ & $\begin{array}{c}\mathbf{F} \\
\text { Value }\end{array}$ \\
\hline $\begin{array}{c}\text { Organizational } \\
\text { Emotional Memory } \\
\text { Level }\end{array}$ & $\begin{array}{c}\text { Organizational } \\
\text { Commitment }\end{array}$ & .570 & .000 & .328 & 292.881 \\
\cline { 3 - 6 } $\begin{array}{c}\text { Relationship- } \\
\text { Oriented Leadership }\end{array}$ & & -.031 & .367 & .328 & 146.803 \\
\hline
\end{tabular}

Hypotheses were evaluated according to the results of regression analysis are shown in Table 7: 
Table 6. Regression Analysis Results

\section{Hypotheses}

H1: There is a relationship between Relationship-Oriented Leadership and Organizational Emotional Memory Level.

H2: There is a relationship between Relationship-Oriented Leadership and Organizational Commitment.

H3: There is a relationship between Organizational

Emotional Memory Level and Organizational Commitment.

\section{Conclusion}

SUPPORTED

NOT SUPPORTED

As a result of the hypothesis tests performed among the variables specified in the research model, except for the effect of the intermediate variable, $\mathrm{H} 1$ and $\mathrm{H} 3$ were supported at the significance level of $\mathrm{p}<0.05$ and $\mathrm{p}<0.001$ as the result of the regression analysis. In the relationships between variables, the $\mathrm{H} 1$ hypothesis was statistically significant in the opposite direction (negative). In other words, a relationshiporiented leadership had an adverse relationship with the level of organizational emotional memory. The

$\mathrm{H} 2$ hypothesis was not supported because there was no significant relationship as a result of the regression analysis conducted on the relationship between variables.

\section{DISCUSSION}

Leaders in teams could be more understanding towards their employees as mentoring them in their business routines. This way, employees feel like more supported. Supporting employees helps them to understand and utilize unique talents in organizations (Henkel, Marion Jr. \& Bourdeau, 2019). It is strongly indicated in the literature that relationship-oriented leadership directly affects organizational emotional memory in a positive way, as it is also supported in the findings. Once the relationship-oriented leaders find their employees' unique talents, they may motivate the talents to outburst their capabilities to enhance the organizational emotional memory levels that can lead to performance increase in the organization.

On the other hand, as a result of the attitudes and behaviors of the employees toward top management, their commitment to the institution lessens and they do not think of themselves as a part of the institution. The main reason of this unexpected negative relationship is caused by the characteristics of the durable goods industry. The research was focused on durable goods industry and the employees seem to have more empathy with task-oriented leadership instead of the relationship-oriented one. Further researches can be conducted to understand the difference among the industries.

A relationship-oriented leadership will let for a more agile project-based work environment, which means the team members can act quickly with the trust of their managers (Farley, 2005). As relationship-oriented leadership based organizational structures, employees feel like they should be agile the most times and it causes not being committed but always into a change for them. Creating friendly environment in the organization by the relationship-oriented leadership, if that trust point goes further as seeing the leader like their daily life friends, that would have an impact as losing thee hierarchy and respect to the power. And it would be ended as not feeling so committed but more free spirit as employees in organizations.

Even though it is found in this research that relationship-oriented leadership has a positive impact on organizational emotional memory level and negative impact on organizational commitment; it is also found that organizational emotional memory level and organizational commitment has a positive relationship. And it is questioned what happens if relationship-oriented leadership effects both organizational emotional memory level and organizational commitment.

The most important point here is, it is normally believed that employees prefer leaders who are friendly to them. It even has a good impact on organizational emotional memory level. However, when the leader is in the operations it decreases organizational commitment. Because employees do not like to feel negative feelings such as worry, anxiety etc. diverted from the leader. There is a fine thin line between "relationshiporiented leadership" and "pushy leadership". In this research, it is observed that these two perspectives are confused. If the leader is always friendly to the employees, they will feel the risk of being flowed by the leader in case they have low performance time-to-time. Their organizational commitment will be affected negatively in the organizations due to negative feelings they start to have. (Overbeek, 2020) 
Employees' organizational emotional memory levels decrease when they face with the attitudes and behaviors of senior management. This also showed that the employees worked more hours than they supposed to within the organization due to intense pace of work, have lower organizational memory levels.

\section{LIMITATIONS AND SUGGESTIONS}

Considering the pace of work, it is essential to observe the level of organizational memory and organizational commitment in different sectors. One of the limitation of this study is the differences between sectors are disregarded. It is suspected that especially public sector can have different levels of relationship between relationship-oriented leadership and organizational commitment. Making a distinction between private or public sectors may reveal other possible results. While private sector employees have a fear of losing their jobs, civil servants working in the public sector have no such fear. Naturally, the occurrence of a compulsory or optional situation should not be expected in this case.

There can also be differences between service and manufacturing sector. The service sector was the scope of this study and creativity is crucial in service sector, therefore the employees can be demotivated when there is excess pressure on them. On the other hand, manufacturing sector has stronger framework. Therefore, it is crucial to re-test the hypothesis in manufacturing and public sectors separately.

The other limitation of the study is the differences between male and female employees were not considered during the analysis. If the sample size was larger to focus on male and females separately, there could be a probability that the differences can be observed for two genders. Additionally, if there was a following qualitative study, it could be possible to shed light on psychological factors that affect the relationshiporiented leadership, organizational memory level and organizational commitment.

The findings of this study can inspire the business professionals to adjust their management skills and enhance the organizational performance. On the other hand, academicians who focus on management sciences can conduct further research in various sectors and add other dimensions especially with qualitative research. 


\section{REFERENCES}

Akgün, A. E., Keskin H., ve Byrne J. C. (2009), "Organizational emotional capability, product and process innovation, and firm performance: An empirical analysis" Journal of Engineering and Technology Management, Vol: 26, pp. 103-130.

Akgün A., Keskin H. ve Bryne J.C (2012), "The Role of Organizational Emotional Memory on Declarative and Procedural Memory and Firm Innovativeness" JPROD INNOV MANAG, Vol. 29, No 3, pp. 432-451.

Akgün A., Keskin H. ve Bryne J.C (2012), “Organizational Emotional Memory” Management Decision, Vol. 50, No 1, pp. 95-114.

Al-Faouri, A. H., Al-Nsour, M. M., \& Al-Kasasbeh, M. M. (2014). The impact of workforce agility on organizational memory. Knowledge Management Research \& Practice, 12(4), 432-442.

Alvesson, M. (2012), Understanding organizational culture - 2nd Edition, SAGE, London.

Antonakis, J., Ashkanasy, N. M. ve Dasborough, M. T. (2009), "Does leadership need emotional intelligence?" The Leadership Quarterly, Vol. 20, pp. 247-261.

Aram H. Massoud, Jameel, A. S. ., \& Abd Rahman Ahmad. (2020). Stimulating Organizational Citizenship Behavior by Applying Organizational Commitment and Satisfaction. International Journal of Social Sciences and Economic Review, 2(2), 20-27.

Ashforth, B. E., Rogers, K. M. ve Corley, K. G. (2011), "Identity in organizations: Exploring cross-level Dynamics” Organization Science, Vol. 22, No 5, pp. 1144-1156.

Aube, C., Rousseau, V., \& Morin, E. M. (2007). Perceived organizational support and organizational commitment. Journal of managerial Psychology.

Benkhoff, B. (1997). Disentangling organizational commitment. Personnel review.

Bradford, David L. ve Cohen, Allan R. (1984), Managing for Excellence : The Guide to Developing High Performance in Contemporary Organizations, Wiley, New York.

Bragg, J. E. ve Andrews, I. R. (1973), "Participative decision making: An experimental study in a hospital" Journal of Applied Behavioral Science, Vol. 9, No 6, pp. 727-735.

Briker, R., Walter, F., \& Cole, M. S. (2020). The consequences of (not) seeing eye-to-eye about the past: The role of supervisor-team fit in past temporal focus for supervisors' leadership behavior. Journal of Organizational Behavior, 41(3), 244-262.

Cooper, M.R. ve Wood, M.T. (1974), "Effects of Member Participation and Commitment in Group Decision Making on Influence, Satisfaction, and Decision Riskiness" Journal of Applied Psychology, Vol. 59, pp. 127-134.

Cote, S. (2014), "Emotional intelligence in organizations" Annual Review of OrganizationalPsychology and Organizational Behavior, Vol. 1, pp. 459-488.

Çelik, H. C. ve Bindak, R. (2005), "Sınıf öğretmenliği bölümü öğrencilerinin matematiğe yönelik tutumlarının çeşitli değişkenlere göre incelenmesi”, Kastamonu Eğitim Dergisi, 13 (2) 427-436.

Farley, C. (2005). HR's role in talent management and driving business results. Employment Relations Today, 32(1), 55-61.

Finegan, J. E. (2000). The impact of person and organizational values on organizational commitment. Journal of occupational and Organizational Psychology, 73(2), 149-169.

Goldstein, Irwin L. (1986), Training in Organizations : Needs Assessment, Development, and Evaluation Monterey, Brooks/Cole Pub. Co., California.

Hair, J. F., Black, W. C., Babin, B. J. ve Anderson, R. E. (2010), Multivariate Data Analysis: A Global Perspective - 7th ed., Upper Saddle River: NJ.

Henkel, T. G., Marion Jr, J. W., \& Bourdeau, D. T. (2019). Project Manager Leadership Behavior: TaskOriented Versus Relationship-Oriented. Journal of Leadership Education, 18(2), 1. 
Holan, P. M. de. (2011), "Organizational Forgetting, Unlearning, and Memory Systems" Journal of Management Inquiry, Vol. 20, No 3, pp. 302-304.

Kim, W. G. ve Brymer, Robert A. (2011), "The effects of ethical leadership on manager job satisfaction, commitment, behavioral outcomes, and firm performance" International Journal of Hospitality Management, Vol. 30, pp. 1020-1026.

Kim, H. ve Yukl, G. (1995), "Relationships of Self-reported and Subordinate-reported Leadership Behaivors to Managerial Effectiveness and Advancement", Leadership Quarterly, Vol. 6, pp. 361-377.

Kluger, A. N. ve DeNisi, A. (1996), "The Effects of Feedback Interventions on Performance: A Historical Review, A Meta-Analysis, and a Preliminary Feedback Intervention Theory”, Psychological Bulletin, Vol. 119, pp. 254-284.

Lowe, K.B., Kroeck, K.G. ve Sivasubramaniam, N. (1996), "Effectiveness of Correlates of Transformational and Transactional Leadership: A Meta-Analytic Review of the MLQ Literature", Leadership Quarterly, Vol. 7, pp. 385-425.

Nunnally, J. C. (1978), Psychometric theory, McGraw-Hill, New York.

Overbeek, Ira (2020) Effective leadership personality dimensions derived from a contextualized lexical research. (http://essay.utwente.nl/83197/)

Patterson, A. J. (2018). Perceptions of Relationship-Oriented Leadership Behaviors: A Descriptive Case Study.

Psdakoff, P.M. ve Todor, W.D. (1995), "Relationship Between Leader Reward and Punishment Behavior and Group Proceess and Productivity", Journal of Management, Vol. 11, pp. 55-73.

Rageb, M. A., Mohamed Abd-el-salam, E., El-Samadicy, A., \& Farid, S. (2014). Organizational Commitment. Job Satisfaction and Job Performance as a mediator between Role Stressors and Turnover Intentions A Study from an Egyptian cultural perspective, IJBED, 1(1).

Rüzgar, N. (2018). The Effect of Leaders' Adoption of Task-Oriented or Relationship-Oriented Leadership Style on Leader-Member Exchange (LMX), In the Organizations That Are Active In Service Sector: A Research on Tourism Agencies. Journal of Business Administration Research, 7(1), 50-60.

Sahertian, P. (2018). The Analysis of Knowledge Management Implementation and Relationship-oriented Leadership Behavior in Developing Organizations' Human Capital.

Snape, E. ve Redman, T. (2010), "HRM Practices, Organizational Citizenship Behaviour,and Performance: A Multi-Level Analysis" Journal of Management Studies, Vol. 47, No 7, pp. 201-223.

Tran, Q. H. (2020). Organisational culture, leadership behaviour and job satisfaction in the Vietnam context. International Journal of Organizational Analysis.

Vroom, Victor H. ve Jago, Arthur G. (1988), The New Leadership : Managing Participation in Organizations, Englewood Cliffs, Prentice Hall, New Jersey.

Yukl, Gary (2002), Leadership in Organizations - Fifth Edition, Prentice Hall Inc., New Jersey.

Zehir, C., Ertosun, Ö. G., Zehir, S., \& Müceldili, B. (2011). The effects of leadership styles and organizational culture over firm performance: Multi-National companies in İstanbul. Procedia-Social and Behavioral Sciences, 24, 1460-1474.

Zeynvand Lorestani, H., \& Feiz, D. (2017). The Effect of Emotional Memory on Organizational Innovation. Organizational Culture Management, 15(4), 903-923. 